\title{
Nurses, nannies and caring work: importation, visibility and marketability
}

\author{
Barbara L. Brush and Rukmini Vasupuram \\ University of Michigan School of Nursing, Ann Arbor, Michigan, USA \\ Accepted for publication 13 February 2006
}

\begin{abstract}
BRUSH B and VASUPURAM R. Nursing Inquiry 2006; 13: 181-185
Nurses, nannies and caring work: importation, visibility and marketability

This paper examines nurses' international migration within the broader context of female migration, particularly against more studied groups of women who have migrated for employment in care-giving roles. We analyze the similarities and differences between skilled professional female migrants (nurses) and domestic workers (nannies and in-home caretakers) and how societal expectations, meanings, and values of care and 'women's work', together with myriad social, cultural, economic and political processes, construct the female migrant care-giver experience. We argue that, as the recruitment of foreign workers gains visibility, strategies are introduced to better prepare female migrant care-givers for the marketplace. Language, specifically command of English and accent modification, is highlighted as one means to assimilate migrant care-givers to host communities.
\end{abstract}

Key words: care, female migration, foreign nurses, women's work.

Over the past five years, foreign nurse recruitment to the United States has intensified to meet a burgeoning national nurse demand (Brush, Sochalski and Berger 2004). With the growth in numbers, the visibility of nurse migrants has also increased, along with efforts to understand this workforce strategy. Much of the literature to date, however, has focused on migrant nurses' demographic characteristics, achievement of licensure to practice, acclimation to new surroundings, and trends and outcomes of nurse migration on donor and recipient countries (Buchan and Sochalski 2004; Dikaya and Appelt 2004; Dugger 2004; Gerrish and Griffith 2004; Stilwell et al. 2004). There has been limited discussion of how nurses, as predominantly women, compare to other women migrating for employment in other care-giving roles or how social, economic and legislative forces construct the female migrant care-giver experience. There is also nominal understanding of why recipient nations import paid workers from other nations to care for individuals' most intimate

Correspondence: Dr B. Brush, University of Michigan School of Nursing, 400 North Ingalls, Ann Arbor, Michigan 48109, USA.

E-mail:<brushb@umich.edu> needs: their bodies, their homes, and their families. Thus, we explore the nexus of societal expectation, meaning, and value of care and 'women's work' from the perspective of origin and destination communities, describe how international female migration exemplifies these constructed meanings and particular categories, and how power relationships and social processes create and sustain them.

\section{CARING AND WOMEN'SWORK}

Women who export abroad for care-giver roles are a subset of migrant women workers who engage in various aspects of nurturing and maintaining peoples' well-being. Whether provided in private homes or in public settings such as hospitals and nursing homes, these services are explicitly connected to women's work and woman's 'inclination' and often involve both physical and emotional components that defy quantification (Tung 2000; Henderson 2001). Like 'women's work' more generally, the work of caring is often invisible, marginalized, and only noticed when it is not provided at expected levels and quality (Cowan 1983). In this analysis, we include women who migrate as nurses and 
as domestic workers (nannies, housekeepers, and in-home care providers). While their skill and educational levels differ substantially, they are actively engaged in the work of caring for individuals, families, and their environments when care is needed or demanded and cannot be provided by local workers.

Women of color dominate domestic worker streams to the United States (Glenn 2000). The race and class chasm between these 'servants of globalization' and their employers is readily apparent. Poor minority women often work in the homes of white and/or affluent families and symbolize their employer's status and success while they themselves struggle with low wages, minimum job security, low or no health benefits, and limited occupational mobility (Momsen 1999; Barber 2000; Chang 2000; Hondagneu-Sotelo 2001; Parreñas 2001; Ehrenreich and Hochschild 2002; Zarembka 2002). Relegated to more private spheres of practice, moreover, they are relatively inconspicuous to all but those who employ them. As such, domestic worker migrants are more prone to job-related gender, race and class discrimination, physical and psychological abuse, and financial exploitation than are women working in more public arenas (Constable 2002; Zarembka 2002; Waldman 2005).

Migrant nurses, on the other hand, have become more conspicuous care-givers as market demand has moved them from predominantly urban healthcare institutions to more 'mainstream' community hospitals (Brush and Berger 2002; Brush, Sochalski and Berger 2004). Thus, where once foreign nurses worked predominantly in minority-rich communities, on night shifts, or in institutions shielded from the white American majority, they are now recruited more widely across American communities and institutions (Brush 1999; Brush, Sochalski and Berger 2004). Given that professional registered nurses in the United States are $82 \%$ white and $94 \%$ female, the shifting complexion and accents of greater numbers of migrant nurses has made them more visible among American nursing staffs (HRSA 2006).

Nurses have rarely been examined as part of, or in comparison to, other women who migrate for caring and service employment. Enticed to leave their home countries by promises of better pay and working conditions, improved learning and practice opportunities, and free travel, licensure, and room and board (Brush, Sochalski and Berger 2004; Kingma 2006), they, like other migrant women, often support family and young children left behind. At the same time they are contributing to their home nation's overall economic health (Hondagneu-Sotelo and Avila 1997; Tung 2000; George 2005). Wages are significantly higher for most nurses who export abroad compared to what they can earn at home and much higher than lesser skilled domestic workers. For example, nurses from the Philippines, where the greatest number of nurses worldwide are exported from, can make an average of $\$ 45780$ and $\$ 41430$ per year in American hospitals and nursing homes, respectively, compared to the \$2000-2400 annual salaries paid in the Philippines (Estella 2005). This translates into enormous earning potential; nurses exporting abroad can make in 1 year in an American hospital what it would take them over 20 years to earn at home.

The international movement of human capital, and of women in particular, has been largely facilitated by lowered trade and political barriers that allow individuals and small businesses to more easily develop and compete for business (Friedman 2005). As a result, the number of recruitment agencies has escalated, capitalizing on the economic disparity faced by many female migrants and serving as brokers between migrating women and the individuals or institutions seeking women for hire. As Chang (1997) noted, 'recruiting agencies and other entrepreneurs on each side of the trade route reap tremendous profits for providing employers in "host" countries with ready and willing service workers and care-givers of all kinds' (136). Because these placements generally occur in a unilateral stream where rich nations draw from the human resources of lesser-developed countries, migrants are often faced with unique and unexpected challenges. Chang (1997) notes, for example, that women migrating to the United States are disadvantaged by the pressure to remit earnings to their home nations while denied access to the protections and rights of American citizenship through stringent immigration policies.

Domestic workers placed in private homes in the United States and other recruiting countries are particularly vulnerable due to the one-on-one nature of their employment. Rendered invisible to all but their immediate supervisors, they are more prone to exploitation and the whims of recruiter and employer gender, race and class stereotypes. For instance, one of the International Nanny Association's Canadian affiliates, who serves a largely white, upper-class clientele, noted, 'A lot of families would like a European, with a culture and standard of living similar to their own' (Bakan and Stasiulis 1995, 310). Likewise, the owner of Nannies Unlimited claimed of her recruits, 'The Filipino girls love babies. They can rock them for hours without losing patience. English nannies are tremendous with twoto-five-year-olds. They play games with them and the Swiss girls are disciplinarians' (Halliday and Smith 1985, 6). Similarly, agencies that place Sri Lankan housemaids in homes in the Middle East value docility among its recruits, as it is more culturally acceptable to those who employ them (Waldman 2005). This 'maid to order' specificity reinforces local, 
cultural and historical stereotypes and creates real and potential situations that undermine workers' human and employment rights (Constable 1997).

Despite employment in more public environments, migrant nurses recruited to US hospitals also face prior legal, professional and cultural hoops that speak to a growing concern that they be both technically and culturally competent to care for the American public (Priester and Reinardy 2003; Brush, Sochalski and Berger 2004). Requirements for English language competency, educational standards, state licensure and visa status have risen in importance with the growth in foreign nurse numbers and their wider geographic distribution. Just as nanny recruitment agencies try to match their recruits with the expectations of the largely upper-class clientele it serves (Bakan and Stasiulis 1995; Waldman 2005), so too do nurse recruitment agencies cater to the demands of a consumer-driven American public; preparing their recruits to understand and assimilate the host country's cultural nuances; ensuring English competency; and assuring employers that nurses are ready for steady employment.

\section{THE INTERNATIONAL NURSING MARKET}

Although nurses have been recruited to the United States for over 50 years, the current and severe US nursing shortage has significantly amplified the importation of skilled migrant nurses (Brush, Sochalski and Berger 2004; Iredale 2005). This crisis in care is not limited to the United States alone. Indeed, the shortage of nurses in many industrialized countries is creating care demands that are being met through nurse importation (Kingma 2006). The Middle East (Saudi Arabia, Kuwait, Libya, Iran, Bahrain and Iraq), parts of Asia (Japan), the UK, Canada and Australia have joined the United States as key destination points for a host of nurse migrants (Buchan, Kingma and Lorenzo 2005).

In response to the global demand for skilled nurses, many lesser developed countries, led by the Philippines and India, are producing nurses to send offshore in greater numbers than domestically required (Choy 2004; George 2005). In addition, active nurse recruitment by developed nations is facilitating a rapid out flux of nurses from many nations at a time when their own health needs have escalated (Kortenbout 1998; Fongwa 2002; US Agency for International Development 2003). Data from the UKCC/Nursing and Midwifery Council on registrants and work permits, for example, showed that the largest number of nurses immigrating to the UK between 1998 and 2003 was from the Philippines (17329), India (3242) and South Africa (5439) (Buchan and Dovlo 2004). Similar trends exist in the United
States; in 2001, 52\% of 8613 nurse migrants were from the Philippines, with 12 and $6 \%$ coming from Canada and Korea, respectively (National Council of State Boards of Nursing 2002). Saudi Arabia is still the number-two destination for nurses from the Philippines and South Africa (Buchan, Kingma and Lorenzo 2005). More recently, the movement of nurses has taken on a more 'carousel' appearance. In addition to moving from developing to developed nations, and from rural to urban communities within countries, nurses are also moving regularly between developed nations (i.e. from the UK to Canada and Canada to the US) (Baumann et al. 2004; Kingma 2006).

Regardless of nurses' final destinations, however, English has become the universal language of migration (DeLong 1996; Jaggar 2002). While language and remedies to assuage the problems of comprehension and expression have been longstanding issues in nurse migration, in the modern-day business of nurse recruitment, the acquisition of an appropriate accent attached to English skills is also gaining popularity. Hospital groups and recruitment agencies have established contracts with companies that prepare informationtechnology and call-center workers in voice modulation and cultural grooming to mediate nurses' accents, and behaviors as well. The accent neutralization service offered by several recruiters to 'fine tune the accents and pronunciation' of their nurse recruits demonstrates the market's shifting expectation of care-givers and underscores what is becoming more important than simply filling staff vacancies. When nurses are imported from other nations, they must be fit for duty, communicate in English, and be accent free (India Resource Center 2004; GlobeMed Resources 2005).

As language competency and accent training become necessary instruments for one's performative role in the global marketplace, they, along with new criteria for 'cultural adaptation' in countries like the UK and US (Gerrish and Griffith 2004; Buchan, Jobanputra and Gough 2005) are contributing to a state of negotiating identities that reflects the 'neither here, nor there' dilemma reported by many nurse migrants (George 2005; Krishnamurthy 2005). This sense of cultural displacement has proven persistent; Asian Indian nurses described having 'a foot here, a foot there, and a foot nowhere' two decades after immigrating to the United States (DiCicco-Bloom 2004, 28). There is limited research to understand the long-term implications of this state of duality on nurses, their families, and their patients. One can speculate, however, that having a foot in two worlds creates a formidable, and often confusing, challenge for women in this situation.

Indeed, Parreñas (2001) describes this ambiguous state of being as the 'dislocation of migration' (23), which, along 
with a sense of non-belonging, includes partial citizenship, the pain of family separation, and contradictory class mobility. Migrant women are particularly vulnerable to this phenomenon as they often negotiate work lives in one place and maintain family connections in their home nations. This is compounded by the work that they do and its link to their societal roles as women; women are constantly balancing their roles as paid care-givers with their roles as family care-givers.

\section{CONCLUSION}

Whether performed as housework or childcare by migrant domestic workers or as skilled patient management by migrant nurses, caring work is fundamentally invisible and devalued. In developed nations, for example, women move away from caring roles as they find employment outside of the home, leaving the care of their children and homes to low-waged foreigners. It has also been increasingly difficult to lure women into nursing under conditions that many women find unacceptable. That is, while nursing is a 'profession' requiring advanced education, skill-building, and decision-making aptitude, it continuously struggles to identify its worth among more traditionally male-dominated healthcare fields such as medicine, dentistry and public health in tangible ways: salary, prestige and work conditions (Apesoa-Varano and Varano 2004; Melchior 2004).

In other words, the recruitment and importation of female care-givers redistributes care to countries less equipped to manage amidst it or less willing or able to provide it. This may further the crisis in caring in donor nations as economic forces push women abroad. As such, the widespread outflow of women may eventually affect the public health and welfare of donor nations. This is evident among African countries sending nurses abroad now (Dugger 2004; Mensah, Abella and Midgley 2005). The global movement of women more broadly is also starting to impact women's relationships and communities at home and abroad, as well as those of men in those countries (George 2005). This creates an additional burden on migrant women moving across international boundaries as they weigh national interests with family responsibilities.

Hiring foreign nurses is no longer a short-term solution to the nursing shortage problem nor is hiring domestic workers a temporary practice in the United States or other industrialized nations. Women are increasingly produced as export products and, with the help of recruitment agencies, processed as products that meet the cultural expectations of competing market buyers. Unless working conditions for nurses and other women improve in lesser developed nations, women will continue to leave for better opportunities abroad that pay more to do what is needed in ever increasing amounts: caring.

\section{REFERENCES}

Apesoa-Varano EC and CS Varano. 2004. Nurses and labor activism in the United States: The role of class, gender, and ideology. Social Justice 31: 77-104.

Bakan AB and DK Stasiulis. 1995. Making the match: Domestic placement agencies and the racialization of women's household work. Signs 20: 303-35.

Barber PG. 2000. Agency in Philippine women's labour migration and provisional diaspora. Women's Studies International Forum 23: 399-411.

Baumann A, J Blythe, C Kolotylo and J Underwood. 2004. Immigration and emigration trends: A Canadian perspective. Ottawa: Nursing Sector Study Corporation.

Brush BL. 1999. Has foreign nurse recruitment impeded African American access to nursing education and practice? Nursing Outlook 47: 175-80.

Brush BL and AM Berger. 2002. Sending for nurses: Foreign nurse migration, 1965-2002. Nursing and Health Policy Review 1: 103-15.

Buchan J and J Sochalski. 2004. The migration of nurses: Trends and policies. Bulletin of the World Health Organization 82: 587-94.

Brush BL, J Sochalski and AM Berger. 2004. Imported care: Recruiting foreign nurses to US health care facilities. Health Affairs 23: 78-87.

Buchan J, R Jobanputra and P Gough. 2005. Should I stay or should I go? Nursing Standard 19: 14-16.

Buchan J, M Kingma and FM Lorenzo. 2005. International migration of nurses: Trends and policy implications. International Council of Nurses, http://www/icn.ch/ global/Issue5migration.pdf (accessed 10 June 2005).

Chang G. 1997. The global trade in Filipina workers. In Dragon ladies: Asian American feminists breathe fire, ed. S Shah, 132-52. Boston: South End Press.

Chang G. 2000. Disposable domestics: Immigrant women workers in the global economy. Cambridge: South End Press.

Choy CC. 2004. Empire of care: Nursing and migration in Filipino American history. Durham: Duke University Press.

Constable N. 1997. Maid to order in Hong Kong: An ethnography of Filipina workers. Ithaca, NY: Cornell University Press.

Constable N. 2002. Filipina workers in Hong Kong homes: Household rules and relations. In Global woman: Nannies, maids, and sex workers in the new economy, eds B Ehrenreich and AR Hochschild, 115-41. New York: Metropolitan Books. 
Cowan RS. 1983. More work for mother: The ironies of household technology from the open hearth to the microwave. New York: Basic Books.

DeLong DF. 1996. My turn: America's new language. BusinessWorld Online, 26 December, 5.

DiCicco-Bloom B. 2004. The racial and gendered experiences of immigrant nurses from Kerala, India. Journal of Transcultural Nursing 15: 26-33.

Dikaya ZA and HF Appelt 2004. Foreign registered nurses: Successful landing in turbulent waters. JONA 34: 379-83.

Dugger CW. 2004. An exodus of African nurses puts infants and the ill in peril. The New York Times, 12 July: A1.

Ehrenreich B and AR Hochschild, eds. 2002. Global woman: Nannies, maids, and sex workers in new economy. New York: Metropolitan Books.

Estella C. 2005. Lack of nurses burdens an ailing healthcare system. http://www.pcij.org/stories/print/2005/nurses. html (accessed 23 August 2005).

Fongwa MN. 2002. International health care perspectives: The Cameroon example. Journal of Transcultural Nursing 13: 325-30.

Friedman TL. 2005. The world is flat: A brief history of the twentyfirst century. New York: Farrar, Straus, and Giroux.

George SM. 2005. When women come first: Gender and class in transnational migration. San Francisco: University of California Press.

Gerrish K and V Griffith 2004. Integration of overseas registered nurses: Evaluation of an adaptation programme. Journal of Advanced Nursing 45: 579-87.

Glenn EN. 2000. Creating a caring society. Contemporary Sociology 29: 84-94.

GlobeMed Resources, LLC News. http://www.globemedresources.com/GlobemedNews.asp (accessed 23 April 2005).

Halliday S and NJ Smith. 1985. How to profit from women's work. Alberta Business Calgary 2: 56.

Health Resources and Services Administration (HRSA). 2006. Preliminary findings: 2004 national sample survey of registered nurses. http://bhpr.hrsa.gov/healthworkforce/ reports/rnpopulation/preliminaryfindings.htm (accessed 13 July 2006).

Henderson A. 2001. Emotional labor and nursing: An underappreciated aspect of caring work. Nursing Inquiry 8: $130-8$.

Hondagneu-Sotelo P. 2001. Domestica: Cleaning and caring in the shadows of affluence. Berkeley: University of California Press.

Hondagneu-Sotelo P and E Avila. 1997. 'I'm here, but I'm there'. The meanings of Latina transnational motherhood. Gender and Society 11: 548-71.

India Resource Center. 2004. India exporting nurses to UK and US. www.indiaresource.org/new/2004/1037.html (accessed 22 March 2005).

Iredale R. 2005. Gender, immigration policies and accreditation: Valuing the skills of professional women migrants. Geoforum 36: 155-66.

Jaggar AM. 2002. A feminist critique of the alleged southern debt. Hypatia 17: 119-42.

Kingma M. 2006. Nurses on the move: Migration in the global health care economy. Ithaca: Cornell University Press.

Kortenbout E. 1998. Production of nurses in South Africa. South African Health Review, http://www.healthlink.org.za/ sahr/98/chap6.htm (accessed 2 June 2003).

Krishnamurthy MS. 2005. Outsourced identities: The foundations of the cross-border economy. SAGAR 14: 23-38.

Melchior F. 2004. Feminist approaches to nursing history. Western Journal of Nursing Research 26: 340-55.

Mensah K, M MacKintosh and L Henry. 2005. The skills drain of health professionals from the developing world: A framework for policy formulation. London: Medact.

Momsen J, ed. 1999. Gender, migration and domestic service. New York: Routledge.

National Council of State Boards of Nursing. 2002. 2001 licensure and examination statistics. Chicago: NCSBN.

Parreñas RS. 2001. Servants of globalization: Women, migration and domestic work. Stanford: Stanford University Press.

Priester R and JR Reinardy. 2003. Recruiting immigrants for long-term care nursing positions. Journal of Aging and Social Policy 15: 1-19.

Stilwell B, K Diallo, P Zurn, M Vujicic, O Adams and M Dal Poz. 2004. Migration of health-care workers. Bulletin of the World Health Organization 82: 595-600.

Tung C. 2000. The cost of caring: The social reproductive labor of Filipina live-in home health caregivers. Frontiers 21: $61-81$.

US Agency for International Development. 2003. The health sector human resource crisis in Africa: An issue paper. http://www.aed.org/publications/HR_IssuesPaper.pdf (accessed 18 June 2003).

Waldman A. 2005. Sri Lankan maids' high price for foreign jobs. The New York Times, 8 May: 1, 6.

Zarembka JM. 2002. America's dirty work: Migrant maids and modern day slavery. In Global woman: Nannies, maids, and sex workers in new economy, eds B Ehrenreich and AR Hochschild, 142-53. New York: Metropolitan Books. 